Original Research Paper

\title{
The Local Knowledge of Medicinal Plants by The Tanjung Merpati Village Community for The Postpartum and Infant Care
}

\author{
Yeni Mariani $^{1 *}$, Fathul Yusro ${ }^{1}$, Evy Wardenaar ${ }^{1}$, Yuliati Indrayani ${ }^{1}$ \\ ${ }^{1}$ Faculty of Forestry, Tanjungpura University, Pontianak, Indonesia
}

\author{
Article History \\ Received : November $25^{\text {th }}, 2021$ \\ Revised : December 05 ${ }^{\text {th }}, 2021$ \\ Accepted : December 20 ${ }^{\text {th }}, 2021$ \\ Published : January $05^{\text {th }}, 2022$ \\ *Corresponding Author: \\ Yeni Mariani, \\ Forestry Faculty, \\ Tanjungpura University, \\ Pontianak \\ Email: \\ yeni.mariani81@gmail.com
}

\begin{abstract}
Women often experience various health problems with their reproductive organs. They also have to take several treatments during postpartum and infant care. In the community, these treatments generally use medicinal plants and become local knowledge. This study aimed to document the local knowledge of Tanjung Merpati Village community in using medicinal plants for postpartum and infant care. We interviewed a total of 96 respondents, who are the general public in Tanjung Merpati Village. The data obtained were analyzed in the form of use-value (UV), informant consensus factor (ICF), and fidelity level (FL). The analysis results showed 22 species of medicinal plants used for postpartum and infant care. Plants such as kunyit kuning (Curcuma longa), cokur (Kaemperia galanga), entomu (Curcuma xanthorriza), and ginger (Zingiber officinale) have the highest UV values with values respectively $(1 ; 0.96 ; 0.84$ and 0.8$)$. Baby haircare shows the highest ICF value. Several plants have the highest FL value (100), namely manjakani (Quercus infectoria) and asam kanis (Garcinia xanthochymus) (postnatal maternal care), ayau (Litsea $s p$ ) (baby poultice), kumis kucing (Orthosiphon aristatus), and coconut (Cocos nucifera) (fever in infants), jackfruit (Artocarpus heterophyllus) (treatment of baby's umbilical wound), lidah buaya (Aloe vera) (baby haircare), mengkudu (Morinda citrifolia) (stomachache and bloating in infants), as well as pisang (Musa sp) and cangkok manis (Sauropus androgynus) (enhance mother breast milk). Conclusions from the results of the study indicate that the people of Tanjung Merpati Village have local knowledge regarding postpartum and infant care, and this knowledge is still well maintained in the community.
\end{abstract}

Keywords: Local knowledge, postpartum and infant care, medicinal plants, Tanjung Merpati Village

\section{Pendahuluan}

Perempuan dalam kehidupannya sering menghadapi berbagai masalah kesehatan terkait organ reproduksi, seperti nyeri pada saat haid dan keputihan ((Rania et al., 2019). Perempuan juga harus melakukan proses seperti melahirkan yang memerlukan perawatan baik itu untuk dirinya sendiri maupun pada bayi yang dilahirkan (Mariani et al., 2021). Setelah melahirkan, mereka harus menjalani perawatan perawatan intensif seperti mengeluarkan darah kotor, mengobati luka dan memulihkan kondisi tubuh. Perempuan juga harus melakukan perawatan pada bayi seperti mengeringkan luka pada pusar bayi serta mengobati bayi saat mengalami demam, batuk dan pilek serta saat bayi mengalami sakit dan kembung pada perutnya ((Pradita et al., 2021);(Yusro et al., 2020)).

Perawatan intensif yang diberikan kepada perempuan setelah melahirkan ini dapat mencegah terjadinya maternity blues yang dapat menyebabkan depresi, dan stress yang akan dapat menyebabkan terhambatnya produksi air susu ibu yang tidak hanya juga akan berdampak pada kesehatan ibu tetapi juga pada bayi (Takahashi and Tamakoshi, 2014).

Pada berbagai daerah di Indonesia, perawatan terhadap ibu setelah melahirkan dan bayi serta untuk mengatasi masalah kesehatan 
terkait organ reproduksinya umumnya masih menggunakan cara tradisional (Silalahi et al., 2020), hal ini juga ditemukan pada masyarakat di Kalimantan Barat dan telah merupakan pengetahuan local di dalam masyarakat ((Yusro et al., 2020); (Rania et al., 2019)).

Desa Tanjung Merpati merupakan salah satu desa di wilayah Kecamatan Kembayan Kabupaten Sanggau Kalimantan Barat. Seperti halnya beberapa desa di Kabupaten Sanggau, masyarakat setempat masih menjaga pengetahuan local dalam penggunaan tumbuhan obat seperti yang dilaporkan oleh (Rahman et al., 2019), (Ningsih et al., 2020); (Pradita et al., 2021); c.

Pengetahuan local masyarakat dalam menggunakan tumbuhan obat terutama dalam mengobati penyakit dan merawat kesehatan, terutama untuk perawatan setelah melahirkan dan mengatasi masalah kesehatan organ kewanitaan. Akan tetapi, hingga saat ini belum ada laporan ilmiah yang mendokumentasikan pengetahuan masyarakat umum desa Tanjung Merpati tersebut.

Hingga saat ini tercatat bahwa masyarakat di beberapa daerah di kabupaten ini seperti di desa Pengadang Kecamatan Sekayam, tepatnya di Dusun Ruis, Dusun Remayan dan Munyau menggunakan 26 jenis, 20 jenis dan 13 jenis tumbuhan obat (Pradita et al., 2021). Untuk di kecamatan Kembayan Kabupaten Sanggau, dokumentasi pengetahuan masyarakat umum terkait penggunaan tumbuhan obat untuk perawatan ibu dan bayi setelah melahirkan dan juga untuk mengatasi masalah kesehatan organ kewanitaan hanya terbatas pada desa Tanap yang menggunakan 32 jenis tumbuhan obat (Mariani et al., 2021), sedangkan untuk desa-desa lainnya di dalam wilayah Kecamatan Kembayan belum dilaporkan.

Penelitian ini bertujuan untuk mendokumentasikan pengetahuan local masyarakat Desa Tanjung Merpati dalam menggunakan tumbuhan obat untuk perawatan ibu dan bayi setelah melahirkan.

\section{Bahan dan Metode}

\section{Lokasi dan Waktu}

Penelitian dilakukan di desa Tanjung Merpati Kecamatan Kembayan Kabupaten Sanggau Kalimantan Barat (Gambar 1).
Pengambilan data dilakukan selama bulan Juni hingga Juli 2021.

\section{Pengumpulan Data}

Pengumpulan data dilakukan terhadap 96 orang yang merupakan masyarakat umum desa Tanjung Merpati. Dari keseluruhan responden, 71 orang diantaranya berjenis kelamin laki-laki dan 25 orang perempuan dengan rentang usia berkisar 17 tahun hingga 65 tahun.

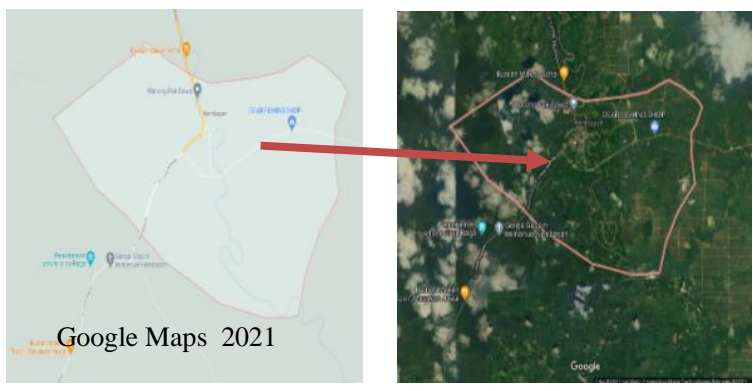

Gambar. 1. Peta desa Tanjung Merpati

Mayoritas responden merupakan suku melayu $(87,5 \%)$ dan memeluk agama Islam, sedangkan 12,5\% merupakan suku Dayak Muara yang beragama katolik dan protestan. Sebanyak $62,5 \%$ responden memiliki profesi sebagai petani, sedangkan sisanya adalah pegawai negeri sipil, pegawai swasta, pedagang dan ibu rumah tangga. Responden tersebut dipilih secara purposive sampling. Teknik wawancara mendalam dengan menggunakan pedoman kuesioner serta pengamatan langsung di lapangan merupakan metode dalam pengumpulan data pengetahuan lokal masyarakat dalam memanfaatkan tumbuhan dalam perawatan ibu dan bayi setelah melahirkan (Mariani et al., 2021).

\section{Analisis Data}

Data yang diperoleh dari wawancara dan pengamatan lapangan selanjutnya dianalisa untuk menentukan nilai guna (use value) atau UV, nilai kesepakatan masyarakat dalam memanfaatkan jenis tumbuhan untuk perawatan tertentu (informant consensus factor) atau ICF serta menentukan jenis tumbuhan yang paling banyak digunakan oleh responden pada penggunaan perawatan tertentu (fidelity level) atau FL. Persamaan yang digunakan untuk analisa tersebut yaitu: (Andrade-Cetto and Heinrich, 2011): 


$$
\mathrm{UV}=\sum \mathrm{Uis} / \mathrm{ns}
$$

UV = Nilai guna suatu jenis tumbuhan

Uis = Jumlah sitasi dari suatu jenis

ns $\quad=$ Jumlah total responden

$$
\mathrm{ICF}=(\mathrm{Nur}-\mathrm{Nt}) /(\mathrm{Nur}-1)
$$

$\mathrm{ICF}=$ Informan consensus factor

Nur = Jumlah sitasi untuk penyakit tertentu

$\mathrm{Nt}=$ Jumlah jenis tumbuhan yang digunakan untuk perawatan tertentu

$\mathrm{FL}(\%)=(\mathrm{Np} / \mathrm{N}) * 100$

$\mathrm{FL} \quad=$ Fidelity level $(\%)$

$\mathrm{Np} \quad=$ Jumlah penggunaan jenis tumbuhan untuk perawatan tertentu

$\mathrm{N} \quad=$ Jumlah total laporan penggunaan untuk semua manfaat dari suatu jenis tumbuhan.

\section{Hasil dan Pembahasan}

\section{Pengetahuan local tumbuhan obat untuk perawatan ibu dan bayi setelah melahirkan}

Pada penelitian ini diperoleh hasil bahwa masyarakat desa Tanjung Merpati memiliki pengetahuan local terkait pemanfaatan tumbuhan obat untuk perawatan ibu dan bayi setelah melahirkan. Hal ini terbukti dengan terdokumentasinya pengetahuan masyarakat tersebut dari responden yang berpartisipasi pada penelitian ini. Semua responden (100\%) menyatakan pernah menggunakan tumbuhan obat untuk perawatan ibu dan bayi setelah melahirkan, baik itu untuk dirinya sendiri maupun untuk anggota keluarga. Pengetahuan lokal ini tidak hanya dimiliki oleh responden perempuan, responden laki-laki juga memiliki pengetahuan ini. Hasil serupa juga dilaporkan oleh (Yusro et al., 2020) pada masyarakat desa Masbangun Kabupaten Kayong Utara dan (Mariani et al., 2021) pada masyarakat desa Tanap Kabupaten Sanggau.

Pada penelitian ini berhasil terdokumentasi sebanyak 22 jenis tumbuhan obat yang digunakan oleh masyarakat desa Tanjung Merpati untuk perawatan ibu dan anak setelah melahirkan. Jumlah jenis tumbuhan yang digunakan oleh masyarakat desa Tanjung
Merpati ini lebih rendah dibandingkan dengan yang digunakan oleh masyarakat desa Tanap yang menggunakan sebanyak 32 jenis (Mariani et al., 2021), akan tetapi lebih tinggi dibandingkan yang digunakan oleh masyarakat desa Masbangun (Yusro et al., 2020). Daftar tumbuhan tersebut selengkapnya disajikan pada Tabel 1.

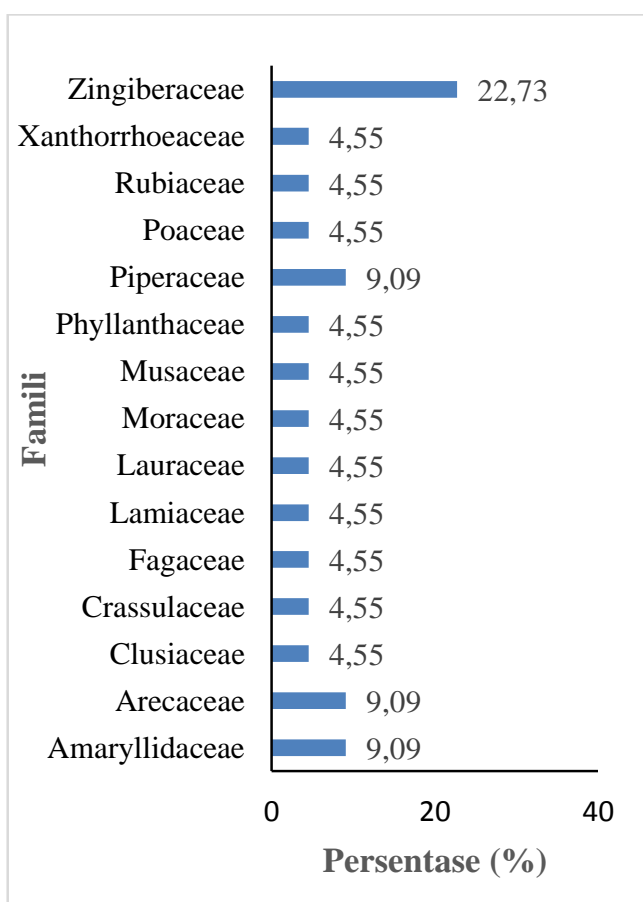

Gambar. 2. Famili Tumbuhan Obat

Tumbuhan yang digunakan oleh masyarakat desa Tanjung Merpati ini berasal dari 15 famili, 5 jenis tumbuhan berasal dari famili Zingiberaceae (22,73\%) (Gambar 2). Jenis tumbuhan dari famili Zingiberaceae telah lama digunakan oleh masyarakat dibeberapa wilayah di Indonesia untuk perawatan paska melahirkan, seperti yang dilaporkan oleh (Saudah et al., 2018) pada masyarakat Keumala di Kabupaten Pidie, Aceh. Tumbuhan famili Zingiberaceae juga digunakan oleh pengobat tradisional di desa Masbangun untuk perawatan setelah melahirkan (Rania et al., 2019).

Beberapa jenis tumbuhan anggota famili Zingiberaceae dilaporkan memiliki aktivitas sebagai antiinflamasi, immunomodulator, antimikroba, antioksidan, antikanker (Wahyuni et al., 2019). Senyawa metabolit sekunder seperti terpenoid, fenolik, zat volatile, alkaloid, tannin, saponin, dan flavonoid ditemukan pada bagian 
rimpang tumbuhan famili ini (Irayanti and Yadnya Putra, 2020).

Beberapa bagian tumbuhan digunakan oleh masyarakat seperti rimpang, bunga, buah dan daun. Bagian tumbuhan yang paling banyak digunakan adalah daun $(40,91 \%)$ dan rimpang $(31,82 \%)$. Penggunaan daun dalam perawatan ibu setelah melahirkan pada masyarakat di berbagai daerah telah cukup banyak dilaporkan ((Lamxay et al., 2011); (Silalahi et al., 2020); (Tsobou et al., 2016).

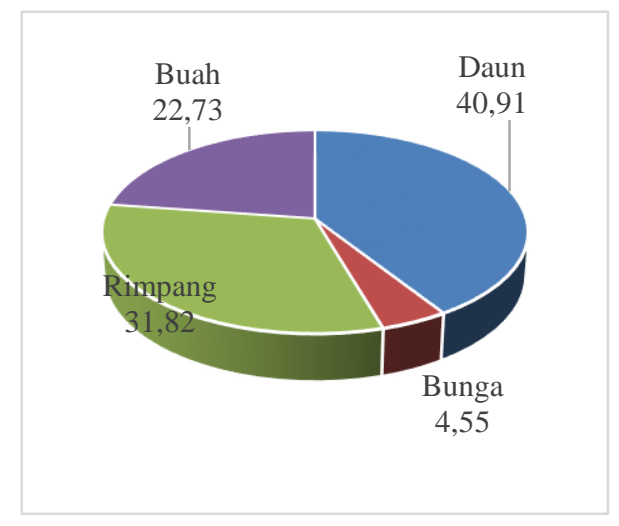

Gambar. 2. Bagian Tumbuhan Obat

\section{Nilai guna tumbuhan obat (Use value)}

Jenis tumbuhan yang memiliki nilai guna (UV) tertinggi yaitu kunyit kuning (C. longa) dengan nilai 1 . Terdapat juga beberapa jenis tumbuhan yang memiliki nilai UV mendekati nilai tertinggi yaitu cokur (K. galanga), entomu (C. xanthorriza) dan jahe ( $Z$. officinale) dengan nilai UV secara berurutan yaitu 0,$96 ; 0,84$ dan 0,8. Keempat jenis tumbuhan tersebut merupakan tumbuhan obat dari famili Zingiberaceae yang telah banyak dikenal dan dimanfaatkan oleh masyarakat secara luas, termasuk dalam perawatan setelah melahirkan, hal ini sesuai dengan hasil penelitian yang dilaporkan oleh (Hartanto et al., 2014) pada masyarakat Pangean Kabupaten Kuantan Riau serta pada masyarakat Using di Kabupaten Banyuwangi (Nurcahyati and Ardiyansyah, 2018).

Bagi masyarakat desa Tanjung Merpati, kunyit kuning memiliki banyak khasiat dan digunakan dalam beberapa jenis perawatan seperti pada perawatan ibu paska melahirkan (membersihkan darah nifas dan menyegarkan badan), melancarkan haid, mengurangi nyeri haid serta mengobati keputihan. Berbagai manfaat yang ditunjukkan oleh tumbuhan ini menjadikannya dikenal secara luas oleh masyarakat desa sehingga seluruh responden pada penelitian ini mengenal dan menggunakannya. Hal inilah yang menyebabkan kunyit kuning memiliki nilai UV tertinggi (1).

Tabel 2. Jenis tumbuhan dan nilai gunanya (UV)

\begin{tabular}{lcc}
\hline \multicolumn{1}{c}{ Jenis Tumbuhan } & Uis & UV \\
\hline Allium cepa & 19 & 0,2 \\
Allium sativum & 53 & 0,55 \\
Aloe vera & 30 & 0,31 \\
Areca catechu & 25 & 0,26 \\
Artocarpus heterophyllus & 29 & 0,3 \\
Cocos nucifera & 16 & 0,17 \\
Curcuma longa & 96 & 1 \\
Curcuma xanthorrhiza & 81 & 0,84 \\
Cymbopogon nardus & 27 & 0,28 \\
Garcinia xanthochymus & 37 & 0,39 \\
Kaempferia galanga & 92 & 0,96 \\
Kalanchoe pinnata & 16 & 0,17 \\
Litsea sp & 40 & 0,42 \\
Morinda citrifolia & 45 & 0,47 \\
Musa sp & 21 & 0,22 \\
Orthosiphon aristatus & 14 & 0,15 \\
Piper betle & 65 & 0,68 \\
Piper nigrum & 18 & 0,19 \\
Quercus infectoria & 33 & 0,34 \\
Sauropus androgynus & 13 & 0,14 \\
Zingiber cassumunar & 30 & 0,31 \\
Zingiber officinale & 77 & 0,8 \\
\hline
\end{tabular}


Mariani, Y et al. (2022). Jurnal Biologi Tropis, 22 (1): 01 - 11

DOI: http://dx.doi.org/10.29303/jbt.v22i1.3156

Tabel 1. Pengetahuan local masyarakat desa Tanjung Merpati dalam perawatan ibu dan bayi setelah melahirkan

\begin{tabular}{|c|c|c|c|c|c|c|c|}
\hline No. & Nama Lokal & Nama Ilmiah & Famili & Manfaat & $\begin{array}{c}\text { Bagian yang } \\
\text { digunakan }\end{array}$ & $\begin{array}{c}\text { Cara } \\
\text { Pengolahan }\end{array}$ & $\begin{array}{c}\text { Cara } \\
\text { Penggunaan }\end{array}$ \\
\hline 1. & Asam kanis & $\begin{array}{l}\text { Garcinia xanthochymus } \\
\text { Hook.f. }\end{array}$ & Clusiaceae & $\begin{array}{l}\text { Perawatan ibu paska } \\
\text { melahirkan }\end{array}$ & Buah & Tumbuk & Tempel \\
\hline 2. & Ayau & Litsea $s p$ & Lauraceae & Tapal bayi & Daun & Tumbuk & Tempel \\
\hline 3. & Banglay & $\begin{array}{l}\text { Zingiber cassumunar } \\
\text { Roxb. }\end{array}$ & Zingiberaceae & $\begin{array}{l}\text { Perawatan ibu paska } \\
\text { melahirkan, tapal bayi, batuk } \\
\text { dan pilek pada bayi }\end{array}$ & Rimpang & Tumbuk & Tempel, gosok \\
\hline 4. & Bawang putih & Allium sativum $\mathrm{L}$. & Amaryllidaceae & $\begin{array}{l}\text { Batuk dan pilek pada bayi, } \\
\text { sakit perut dan kembung pada } \\
\text { bayi }\end{array}$ & Umbi & Tumbuk & Minum \\
\hline 5. & $\begin{array}{l}\text { Bawang } \\
\text { merah }\end{array}$ & $\begin{array}{l}\text { Allium cepa L. var. } \\
\text { aggregatum }\end{array}$ & Amaryllidaceae & $\begin{array}{l}\text { Tapal bayi, sakit perut dan } \\
\text { kembung pada bayi serta } \\
\text { demam pada bayi }\end{array}$ & Umbi & Tumbuk & Tempel \\
\hline 6. & Cangkok & $\begin{array}{l}\text { Sauropus androgynus } \\
\text { (L.) Merr. }\end{array}$ & Phyllanthaceae & $\begin{array}{l}\text { Melancarkan air susu ibu } \\
\text { (ASI) }\end{array}$ & Daun & Rebus & Makan \\
\hline 7. & Cekur & Kaempferia galanga $\mathrm{L}$. & Zingiberaceae & $\begin{array}{l}\text { Perawatan ibu paska } \\
\text { melahirkan, tapal bayi, batuk } \\
\text { pilek pada bayi, sakit perut } \\
\text { dan kembung pada bayi, } \\
\text { melancarkan haid dan } \\
\text { mengurangi nyeri haid, } \\
\text { keputihan }\end{array}$ & Rimpang & Tumbuk, parut & Tempel, makan \\
\hline 8. & Entomu & $\begin{array}{l}\text { Curcuma xanthorrhiza } \\
\text { Roxb. }\end{array}$ & Zingiberaceae & $\begin{array}{l}\text { Perawatan ibu paska } \\
\text { melahirkan }\end{array}$ & Rimpang & Tumbuk, parut & Tempel, makan \\
\hline 9. & Jahe & $\begin{array}{l}\text { Zingiber officinale } \\
\text { Roscoe }\end{array}$ & Zingiberaceae & $\begin{array}{l}\text { Perawatan ibu paska } \\
\text { melahirkan, melancarkan haid } \\
\text { dan mengurangi nyeri haid, } \\
\text { keputihan }\end{array}$ & Rimpang & Tumbuk, parut & Tempel, minum \\
\hline 10. & Kecolap & Kalanchoe pinnata Pers. & Crassulaceae & Demam pada bayi & Daun & Tidak diolah & Gosok \\
\hline 11. & Kelapa & Cocos nucifera Linn. & Arecaceae & Demam pada bayi & Buah & Tidak diolah & Mandi \\
\hline 12. & Kunyit kuning & Curcuma longa $\mathrm{L}$. & Zingiberaceae & $\begin{array}{l}\text { Perawatan ibu paska } \\
\text { melahirkan, tapal bayi, batuk } \\
\text { dan pilek pada bayi, } \\
\text { melancarkan haid dan } \\
\text { mengurangi nyeri haid, } \\
\text { demam pada bayi }\end{array}$ & Rimpang & Rebus, parut & $\begin{array}{l}\text { Ditempel, } \\
\text { digosok }\end{array}$ \\
\hline
\end{tabular}


Mariani, Y et al. (2022). Jurnal Biologi Tropis, 22 (1): 01 - 11 DOI: http://dx.doi.org/10.29303/jbt.v22i1.3156

\begin{tabular}{|c|c|c|c|c|c|c|c|}
\hline No. & Nama Lokal & Nama Ilmiah & Famili & Manfaat & $\begin{array}{c}\text { Bagian yang } \\
\text { digunakan }\end{array}$ & $\begin{array}{c}\text { Cara } \\
\text { Pengolahan }\end{array}$ & $\begin{array}{c}\text { Cara } \\
\text { Penggunaan }\end{array}$ \\
\hline 13. & Kumis kucing & $\begin{array}{l}\text { Orthosiphon aristatus } \\
\text { (Blume) Miq. }\end{array}$ & Lamiaceae & Demam pada bayi & Daun & Tidak diolah & Mandi \\
\hline 14. & Lidah buaya & Aloe vera Burm.f & Xanthorrhoeaceae & Menyuburkan rambut bayi & Daun & Tumbuk & Gosok \\
\hline 15. & Manjakani & Quercus infectoria Oliv. & Fagaceae & $\begin{array}{l}\text { Perawatan ibu paska } \\
\text { melahirkan }\end{array}$ & Buah & Tumbuk & Minum \\
\hline 16. & Mengkudu & Morinda citrifolia $\mathrm{L}$. & Rubiaceae & $\begin{array}{l}\text { Sakit perut dan kembung pada } \\
\text { bayi }\end{array}$ & Daun & $\begin{array}{l}\text { Tidak diolah, } \\
\text { dibakar }\end{array}$ & Tempel \\
\hline 17. & Nangka & $\begin{array}{l}\text { Artocarpus heterophyllus } \\
\text { Lamk }\end{array}$ & Moraceae & Perawatan luka pusar bayi & Daun & Tumbuk & Tempel \\
\hline 18. & Pinang & Areca catechu Linn. & Arecaceae & $\begin{array}{l}\text { Tapal bayi, demam pada bayi, } \\
\text { menunda kehamilan }\end{array}$ & Buah & Tumbuk & Tempel, minum \\
\hline 19. & Pisang & Musa sp & Musaceae & Melancarkan ASI & $\begin{array}{l}\text { Bakal buah/ } \\
\text { jantung }\end{array}$ & Rebus & Makan \\
\hline 20. & Sahang & Piper nigrum L. & Piperaceae & $\begin{array}{l}\text { Perawatan ibu paska } \\
\text { melahirkan, mengobati luka } \\
\text { pusar bayi, sakit perut dan } \\
\text { kembung pada bayi }\end{array}$ & Biji & Tumbuk & tempel \\
\hline 21. & Sirih & Piper betle L. & Piperaceae & $\begin{array}{l}\text { Tapal bayi, mengobati luka } \\
\text { pusar bayi, sakit perut dan } \\
\text { kembung pada bayi, } \\
\text { keputihan, menunda } \\
\text { kehamilan, demam pada bayi }\end{array}$ & Daun & $\begin{array}{l}\text { Tumbuk, } \\
\text { rebus }\end{array}$ & Tempel, minum \\
\hline 22. & Serai wangi & $\begin{array}{l}\text { Cymbopogon nardus } \\
\text { (D.C) }\end{array}$ & Poaceae & $\begin{array}{l}\text { Perawatan ibu paska } \\
\text { melahirkan, sakit perut pada } \\
\text { bayi, kembung pada bayi }\end{array}$ & Daun & Rebus & Mandi \\
\hline
\end{tabular}


Banyaknya kandungan senyawa bioaktif yang dimiliki oleh kunyit kuning $(C$. longa) seperti kurkumin, demethoxycurcumin, bisdemethoxycurcumin, fenilpropen, alkaloid, steroids, dan asam lemak (Li et al., 2011) menjadikannya memiliki aktivitas sebagai analgesic, hepatoprotektif, antiseptik, kardioprotektif, antifungal, antioksidan, antimalaria, antiinflamasi dan antioksidan (Hamaguchi et al., 2010).

Cokur ( $K$. galanga $)$ digunakan oleh masyarakat untuk perawatan paska melahirkan, tapal bayi, batuk dan pilek pada bayi serta mengobati sakit perut dan kembung pada bayi. Penggunaan serupa juga ditemukan pada masyarakat desa Tanap (Mariani et al., 2021). Tumbuhan ini mengandung beberapa senyawa metabolit sekunder seperti ethyl-pmethoxycinnamate, methylcinnamate, carvone, eucalyptol dan pentadecane, dengan memiliki senyawa-senyawa tersebut membuat $K$. galanga memiliki aktivitas biologi seperti sebagai antiinflamasi, analgesik, anti-diare, anti-oksidan, anti-helmint, anti-bakteri dan lainnya (Cahyawati, 2020).

Tabel 3. Informant consensus factor (ICF) dan fidelity level (FL) pengetahuan lokal masyarakat desa Tanjung Merpati untuk perawatan ibu dan bayi setelah melahirkan

\begin{tabular}{|c|c|c|c|}
\hline No. & Kategori Perawatan & Jenis Tumbuhan dan FL & ICF \\
\hline 1. & $\begin{array}{l}\text { Perawatan ibu paska } \\
\text { melahirkan }\end{array}$ & $\begin{array}{l}\text { Kunyit kuning }(22,64) \text {, serai wangi }(69,23) \text {, jahe }(43,5) \text {, } \\
\text { cekur }(25,56) \text {, entomu }(51,27) \text {, sahang }(33,33) \text {, } \\
\text { manjakani }(100) \text {, banglay }(33,33) \text {, asam kanis }(100)\end{array}$ & 0,984 \\
\hline 2. & Tapal bayi & $\begin{array}{l}\text { Kunyit kuning }(22,64) \text {, bawang merah }(36,05) \text {, cekur } \\
(25,56) \text {, sirih }(20,19) \text {, banglay }(33,33) \text {, pinang }(33,33) \text {, } \\
\text { ayau }(100)\end{array}$ & 0,985 \\
\hline 3. & Batuk dan pilek pada bayi & $\begin{array}{l}\text { Kunyit kuning }(21,93) \text {, cekur }(12,62) \text {, banglay }(33,33) \text {, } \\
\text { bawang putih }(50)\end{array}$ & 0,984 \\
\hline 4. & Demam pada bayi & $\begin{array}{l}\text { Kunyit kuning }(11,08) \text {, sirih }(8,07) \text {, bawang merah } \\
(33,33) \text {, kecolap }(100) \text {, pinang }(33,33) \text {, kumis kucing } \\
(100) \text {, kelapa }(100)\end{array}$ & 0,969 \\
\hline 5. & Perawatan luka pusar bayi & Nangka (100), sahang $(33,33)$, sirih $(20,19)$ & 0,982 \\
\hline 6. & Perawatan rambut bayi & Lidah buaya (100) & 1 \\
\hline 7. & $\begin{array}{l}\text { Sakit perut dan kembung } \\
\text { pada bayi }\end{array}$ & $\begin{array}{l}\text { Serai wangi }(30,77) \text {, cekur }(13,11) \text {, entomu }(48,73) \text {, sirih } \\
(11,18) \text {, bawang merah }(30,61) \text {, bawang putih }(50) \text {, } \\
\text { sahang }(33,33) \text {, mengkudu }(100)\end{array}$ & 0,977 \\
\hline 8. & $\begin{array}{l}\text { Menambah air susu ibu } \\
\text { (ASI) }\end{array}$ & Pisang (100), cangkok (100) & 0,970 \\
\hline 9. & $\begin{array}{l}\text { Memperlancar haid dan } \\
\text { mengurangi nyeri haid }\end{array}$ & Kunyit kuning $(21,7)$, jahe $(43,5)$, cekur $(23,3)$ & 0,992 \\
\hline 10. & Keputihan & Sirih $(20,19)$, jahe $(12,99)$, cekur $(6,31)$ & 0.982 \\
\hline 11. & Menunda kehamilan & Sirih $(20,19)$, pinang $(33,33)$ & 0,989 \\
\hline
\end{tabular}

C. xanthorriza atau entomu merupakan salah satu tumbuhan obat yang secara tradisional banyak digunakan dalam jamu dan telah terbukti memiliki aktivitas sebagai antidiuretik, anti-inflammasi, anti-oksidan, antihipertensi, anti-hepatosik, anti-bakterial dan anti-jamur. Kemampuan aktivitas biologis yang dimiliki oleh rimpang tumbuhan ini dikarenakan mengandung beberapa senyawa kimia seperti xanthorrihizol dan curcumene serta senyawa volatil lainnya (Salleh et al., 2016) Pemanfaatan yang dilakukan oleh masyarakat desa Tanjung Merpati terhadap jenis tumbuhan ini adalah sebagai bahan pada perawatan ibu setelah melahirkan.

\section{Informant Consensus Factor (ICF)}

Nilai kesepakatan masyarakat dalam penggunaan suatu jenis tumbuhan obat dalam perawatan atau pengobatan suatu penyakit tertentu dinyakan dalam Informant consensus factor (ICF) (Faruque et al., 2018). Pada penelitian ini, 22 jenis tumbuhan yang digunakanoleh masyarakat desa Tanjung Merpati digunakan pada 11 jenis kategori perawatan untuk ibu dan bayi setelah 
melahirkan. Nilai ICF untuk kategori perawatan tersebut berkisar 0,977-1 (Tabel 3).

Nilai ICF tertinggi diperoleh dari kategori perawatan rambut bayi (1) dengan jenis tumbuhan yang digunakan adalah lidah buaya (A. vera). Menurut (Andrade-Cetto and Heinrich, 2011), nilai ICF yang tinggi dihasilkan ketika suatu kategori penyakit atau perawatan tersebut menggunakan 1 atau beberapa jenis tumbuhan saja, dan ini menunjukkan bahwa responden sepakat terhadap khasiat tumbuhan tersebut.

\section{Fidelity Level (FL)}

Fidelity level (FL) mengindikasikan proporsi persentase sitasi yang menyatakan penggunaan suatu jenis tumbuhan pada perawatan tertentu terhadap seluruh sitasi tumbuhan tersebut tersebut untuk jenis perawatan lainnya (Tugume et al., 2016). Nilai FL ini juga dapat memberikan gambaran jenis tumbuhan yang paling disukai oleh masyarakat untuk digunakan pada suatu jenis perawatan kesehatan (Tangjitman et al., 2015).

Beberapa tumbuhan yang digunakan oleh masyarakat desa Tanjung Merpati memiliki nilai FL yang tinggi (100), diantaranya adalah manjakani dan asam kanis (perawatan ibu paska melahirkan), ayau (tapal bayi), kumis kucing dan kelapa (demam pada bayi), nangka (perawatan pada luka pusar bayi), lidah buaya (perawatan rambut bayi), mengkudu (sakit perut dan kembung pada bayi), serta pisang dan cangkok (perawatan menambah air susu ibu).

Manjakani ( $Q$. infectoria) digunakan secara tradisional oleh masyarakat desa Tanjung Merpati dalam rangkaian perawatan ibu paska melahirkan untuk merapatkan organ kewanitaan setelah proses melahirkan. Secara ilmiah tumbuhan ini telah terbukti mengandung senyawa bioaktif seperti fenol, flavonoid, tannin, saponin, alkaloid dan terpenoid (Wijayanti, 2020). Manjakani juga telah terbukti memiliki aktivitas biologis seperti antidiabetes, antitremorine, anestesilokal, antipyretik, antiinflammasi, antibakteri, antifungal, antivirus dan lainnya. Secara tradisional, manjakani dilaporkan digunakan dalam perawatan paska melahirkan untuk mengobati luka pada organ reproduksi setelah melahirkan (Himalaya, 2018).
Asam kanis (G. xanthochymus) digunakan dalam perawatan paska melahirkan untuk merapatkan organ kewanitaan dan memberikan efek menyegarkan. Menurut (Desmiaty et al., 2021), biji tanaman ini mengandung protein, karbohidrat, serat, asam lemak, sedangkan lemak dari biji asam kanis ini mengandung asam mysristik, asam palmatik, asam stearate, asam palmitolik, asam oleic, asam linoleate, asam arachidic, dan asam behenic. Bagian kulit batangnya terbukti memiliki aktivitas antiinflammasi, sedangkan daunnya mengandung karbohidrat, glikosida, flavonoid dan tannin (Ambarwati et al., 2017).

Lidah buaya (A. vera) kaya akan komponen bioaktif seperti antrakuinon dan turunannya (Lee et al., 2013), asam cinnamic dan turunannya, chromones dan turunannya, anthracene dan turunannya serta flavonoid dan turunannya (Quispe et al., 2018). Pemanfaatan lidah buaya dalam perawatan rambut telah lama digunakan oleh masyarakat Kalimantan Barat, tidak hanya pada masyarakat desa Tanjung Merpati, tetapi juga pada masyarakat dayak di desa Seluan Kabupaten Kapuas Hulu (Liliyanti et al. 2021). Lidah buaya dikenal mampu mengatasi ketombe, menyuburkan rambut serta menjaga kesehatan rambut dan kulit kepala (Ambarwati et al., 2020).

Pada perawatan untuk mengobati perut bayi yang sakit dan kembung, masyarakat desa Tanjung Merpati menggunakan daun mengkudu ( $M$. citrifolia). Hasil pengujian ilmiah menunjukkan bahwa tanaman ini mengandung senyawa metabolit sekunder seperti flavonoid, lignan, irinoid, coumarin, anthrakuinon, polisakarida, terpenoid, sterol, asam lemak dan glikosida (Youn and Chang, 2017). Penggunaan mengkudu untuk mengobati sakit perut dan kembung pada bayi juga dilaporkan oleh (Mariani et al., 2021) pada masyarakat desa Tanap Kabupaten Sanggau. Mengkudu juga digunakan oleh suku Dayak Muara di Kabupaten Sanggau untuk mengatasi masalah pencernaan (Yusro et al. 2021).

\section{Kesimpulan}

Masyarakat desa Tanjung Merpati masih memiliki pengetahuan local terkait penggunaan tumbuhan obat dalam perawatan 
ibu dan bayi setelah melahirkan. Tercatat sebanyak 22 jenis tumbuhan obat digunakan untuk 11 jenis perawatan yang meliputi perawatan paska melahirkan, memperlancar air susu ibu, memperlancar haid dan mengurangi nyeri haid, mengobati keputihan, menunda kehamilan secara alami, tapal bayi, batuk dan pilek, perawatan rambut, perawatan luka pusar bayi, mengobati sakit perut dan kembung pada bayi serta mengobati demam pada bayi. Beberapa tumbuhan memiliki nilai penggunaan yang tinggi yaitu kunyit kuning (C. longa) (1), cokur $(K$. galanga) $(0,96)$, entomu $(C$. xanthorriza) $(0,84)$ dan jahe (Z. officinale) $(0,8)$.

Jenis perawatan yang memiliki nilai ICF tertinggi yaitu pada perawatan rambut bayi. Tumbuhan yang memiliki nilai FL tertinggi (100), yaitu yaitu manjakani ( $Q$. infectoria) dan asam kanis (G. xanthochymus) (perawatan ibu paska melahirkan), ayau (Litsea $s p$ ) (tapal bayi), kumis kucing (O. aristatus) dan kelapa (C. nucifera) (demam pada bayi), nangka (A. heterophyllus) (perawatan pada luka pusar bayi), lidah buaya (A. vera) (perawatan rambut bayi), mengkudu ( $M$. citrifolia) (sakit perut dan kembung pada bayi), serta pisang (Musa sp) dan cangkok ( $S$. androgynus) (perawatan menambah air susu ibu). Penelitian ini merupakan pendokumentasian pengetahuan local masyarakat umum dalam menggunakan tumbuhan obat untuk perawatan ibu dan bayi setelah melahirkan, diperlukan penelitian untuk pendokumentasikan pengetahuan lokal tumbuhan obat yang dimiliki oleh pengobat tradisional yang membantu dan merawat ibu pada saat melahirkan agar pengetahuan lokal dalam pemanfaatan tumbuhan obat dapat terdokumentasi secara komprehensif.

\section{Ucapan terima kasih}

Penelitian ini didanai oleh Dana DIPA Fakultas Kehutanan Universitas Tanjungpura tahun 2021. Ucapan terima kasih juga disampaikan kepada masyarakat Desa Tanjung Merpati Kecamatan Kembayan Kabupaten Sanggau yang telah bersedia menjadi responden dalam penelitian ini.

\section{Referensi}

Ambarwati, N. S. S. Ellya, B., Malik, A., \& Hanafi, M. (2017). Evaluation of antimicrobial activities of Garcinia Latissima Miq. Stem bark extract. Journal of Young Pharmacists, 9(1), pp. S56-S59. doi: 10.5530/jyp.2017.1s.15.

Ambarwati, N. S. S. Supiani. T., Laksmi, N.A. \& Atmanto, D. (2020). Peningkatan Kesejahteraan Dengan Pemanfaatan Lidah Buaya Untuk Perawatan Kulit Kepala Dan Rambut. JKKP (Jurnal Kesejahteraan Keluarga dan Pendidikan), 7(02), pp. 117-129. doi: 10.21009/jkkp.072.01.

Andrade-Cetto, A. and Heinrich, M. (2011) From the field into the lab: Useful approaches to selecting species based on local knowledge. Frontiers in Pharmacology, APR(April), pp. 1-5. doi: 10.3389/fphar.2011.00020.

Desmiaty, Y., Ambarwati, N.N.S., Elya, B., Atmanto, D., \& Ahmad, I. (2021). Elastase inhibitory activity of methanol extract and n-hexane extract of Garcinia xanthochymus Pericarp. Journal of Physics: Conference Series, 1869(1). doi: 10.1088/1742-6596/1869/1/012063.

Faruque, M. O., Uddin, S.B., Hu, S., Dong, S., Cai, Q., Li, X., \& Hu, X. (2018). Quantitative ethnobotany of medicinal plants used by indigenous communities in the Bandarban district of Bangladesh. Frontiers in Pharmacology, 9(FEB). doi: 10.3389/fphar.2018.00040.

Hamaguchi, T., Ono, K. \& Yamada, M. (2010). Curcumin and Alzheimer's disease. CNS Neuroscience and Therapeutics, 16(5), pp. 285-297. doi: 10.1111/j.17555949.2010.00147.x.

Hartanto, S., Sofiyanti, N. \& Fitmawati. (2014). Studi Etnobotani Famili Zingiberaceae dalam Kehidupan Masyarakat Lokal di Kecamatan Pangean Kabupaten Kuantan Singingi, Riau. Biosaintifika: Journal of 
Biology \& Biology Education, 6(2), pp. 98-108. doi: 10.15294/biosaintifika.v6i2.3105.

Himalaya, D. (2018). Pengaruh Pemberian Ekstrak Biji Manjakani (Quercus Infectoria Gall)Terhadap Bakteri Vaginosis Dan Candida Penyebab Keputihan (Leukorrhea). Journal of Midwifery, 5(1), pp. 38-44. doi: 10.37676/jm.v5i1.570.

Irayanti, A., \& Yadnya Putra, A. . G. R. (2020). A Narrative Review of Zingiberaceae Family As Antibacterial Agent for Traditional Medication Based on Balinese Local Wisdom. Journal of Pharmaceutical Science and Application, 2(2), p. 66. doi: 10.24843/jpsa.2020.v02.i02.p04.

Lamxay, V., de Boer, H. J., \& Björk, L. (2011). Traditions and plant use during pregnancy, childbirth and postpartum recovery by the Kry ethnic group in Lao PDR. Journal of Ethnobiology and Ethnomedicine. BioMed Central Ltd, 7(1), p. 14. doi: 10.1186/1746-4269-714.

Lee, Y. S., Ju, H.K., Lim, Tae-Gyu., Uddin, M.R., Kim, Y.B., Baek, J.H., Kwon, S.K., Lee, K.W., Seo, H.S., Park, S.U., \& Yang, Tae-Jin. (2013). Enhancement of anti-inflammatory activity of Aloe vera adventitious root extracts through the alteration of primary and secondary metabolites via salicylic acid elicitation. PLoS ONE, 8(12). doi: 10.1371/journal.pone.0082479.

Li, S., Yuan, W., Deng, G., Wang, P., \& Yang, P. (2011). Chemical Composition and Product Quality Control of Turmeric (Curcuma longa L.), Pharmaceutical Crops, 5(1), pp. 28-54. doi: $10.2174 / 2210290601102010028$.

Mariani, Y., Wardenaar, E., \& Yusro, F. (2021). Tumbuhan Berkhasiat Obat di Desa Tanap Kabupaten Sanggau Dan Pemanfaatannya Untuk Perawatan Bayi dan Perempuan Pasca Persalinan. Biosains, 7(2), pp. 92-102. Available at: https://doi.org/10.24114/jbio.v5i2.13984 \%OAISSN.

Ningsih, K., Mariani, Y., Arbiatutie, Y., \& Yusro, F. (2020). Studi Pemanfaatan Tumbuhan Obat Berpotensi Mengobati Pada Penyakit Pada Penyakit Sistem Pencernaan Di Kelurahan Bunut Kecamatan Kapuas Kabupaten Sanggau. Jurnal Hutan Lestari, 8(2), pp. 217-228. doi: 10.26418/jhl.v8i2.39782.

Nurcahyati, N., \& Ardiyansyah, F. (2018). Kajian Etnobotani Tanaman Famili Zingiberaceae Pada Masyarakat Suku Using Kabupaten Banyuwangi. Biosense, 1(1), pp. 24-35.

Pradita, S., Mariani, Y., Wardenaar, E., \& Yusro, F. (2021). Pemanfaatan Tumbuhan Obat oleh Suku Dayak Paus dan Melayu untuk Perawatan Ibu dan Anak Pasca Persalinan di Desa Pengadang (The Utilization of Medicinal Plants by Dayak Paus and Malay Tribes for Post-Partum Care on Mother and Child in Pengadang Village. Jurnal Biologi dan Pembelajarannya, 16(1), pp. 93-110.

Quispe, C., Villabobos, M., Borquez, J., \& Simirgiotis, M. (2018). Chemical Composition and Antioxidant Activity of Aloe vera from the Pica Oasis (Tarapacá, Chile) by UHPLC-Q/Orbitrap/MS/MS. Journal of Chemistry, 2018. doi: 10.1155/2018/6123850.

Rahman, K., Wardenaar, E., \&Mariani, Y. (2019) 'Identifikasi Jenis Dan Pemanfaatan Tumbuhan Obat Di Hutan Tembawang Oleh Masyarakat Kelurahan Beringin Kecamatan Kapuas Kabupaten Sanggau', Jurnal Hutan Lestari, 7(1), pp. 44-55. doi: 10.26418/jhl.v7i1.30996.

Rania., Yusro, N.,Wardenaar, E., \& Mariani, Y. (2019). Studi Pemanfaatan Tumbuhan Obat Oleh Pengobat Tradisional Untuk Mengatasi Masalah Kewanitaan di Desa 
Masbangun Kecamatan Teluk Batang Kabupaten Kayong Utara. Borneo Akcaya, 5(2), pp. 84-94.

Salleh, N., Ismail, S., \& Ab Halim, M. R. (2016). Effects of Curcuma xanthorrhiza extracts and their constituents on phase II drug-metabolizing enzymes activity. Pharmacognosy Research, 8(4), pp. 309-315. doi: 10.4103/09748490.188873.

Saudah, S., Ernilasari, Suzanni, M.A., Irhamni. \& Diana. (2018). Inventarisasi Tumbuhan Obat Family Zingiberaceae di Masyarakat Keumala Kabupaten Pidie. Talenta Conference Series: Tropical Medicine (TM), 1(3), pp. 074 077. doi: $10.32734 / \mathrm{tm} . v 1 \mathrm{i} 3.265$.

Silalahi, M., Khairiah, A., \&Nisyawati (2020). Ethnomedicinal plants and practices related to pregnancy, childbirth, and postpartum healthcare of minangkabau ethnic group, West Sumatra, Indonesia. Biodiversitas, 21(10), pp. 4597-4605. doi: 10.13057/biodiv/d211018.

Takahashi, Y., \& Tamakoshi, K. (2014). Factors associated with early postpartum maternity blues and depression tendency among Japanese mothers with full-term healthy infants. Nagoya journal of medical science, 76(1-2), pp. 129-138. doi: 10.18999/nagjms.76.1-2.129.

Tangjitman, K., Wongsawad, C., Kamwong, K., Sukko, T., \& Trisonthi, C. (2015). Ethnomedicinal plants used for digestive system disorders by the Karen of northern Thailand. Journal of Ethnobiology and Ethnomedicine, 11(1), pp. 11-27. doi: 10.1186/s13002-0150011-9.

Tsobou, R., Mapongmetsem, P. M., \& Van Damme, P. (2016). Medicinal Plants Used for Treating Reproductive Health Care Problems in Cameroon, Central Africa1. Economic Botany, 70(2), pp. 145-159. doi: 10.1007/s12231-0169344-0.
Tugume, P., Kakudidi, E.K., Buyinza, M., Namaalwa, J., Kamatenesi, M., Mucunguzi, P., \& Kalema, J. (2016) Ethnobotanical survey of medicinal plant species used by communities around Mabira Central Forest Reserve, Uganda. Journal of Ethnobiology and Ethnomedicine. Journal of Ethnobiology and Ethnomedicine, 12(1), pp. 1-28. doi: 10.1186/s13002-015-0077-4.

Wahyuni, D. S. C., Kristanti, M., Marliyana, S.D., \& Rinanto, Y. (2019). Metabolomic Study of Three Species in Zingiberaceae Family based on $1 \mathrm{H}-$ NMR. Majalah Obat Tradisional, 24(1), p. 59. doi: 10.22146/mot.41071.

Wijayanti, I., Shahib, M.N, \& Sastramihardja, H.S. (2020). The Effect of Douching Treatments Using Manjakani Seeds (Quercus infectoria Gall) Boiled Into Water to Total Cololny of Streptococcus sp and Escherichia coli Among IUD Acceptors Who Experienced Vaginal Discharge. Journal of applied measurement, 6(4), pp. 1-20.

Youn, U. J., \& Chang, L. C. (2017) 'Chemical constituents of fermented noni (Morinda citrifolia) juice exudates and their biological activity', Natural Product Sciences, 23(1), pp. 16-20. doi: 10.20307/nps.2017.23.1.16.

Yusro, F., Rania., Mariani, Y., Wardenaar, E., \& Arbiatutie, Y. (2020). Tumbuhan Obat di Lingkungan Sekitar dan Tingkat Pemanfaatannya Untuk Kesehatan Wanita di Desa Masbangun, Kabupaten Kayong Utara. jurnal Biologi Makasar, 5(1), pp. 186-198.

Yusro, F., Mariani, Y., \& Wardenaar, E. (2021). The Utilization of Medicinal Plants to Overcome Gastric Disorders by The Dayak Muara Tribe in Kuala Dua Village, Sanggau Regency. Jurnal Biologi Tropis, 21(2), 416. https://doi.org/10.29303/jbt.v21i2.2638 